\title{
WHAT REGULATIONS FOR ICT-BASED MOBILITY SERVICES IN URBAN TRANSPORTATION SYSTEMS? THE CASES OF RIDE-BOOKING REGULATION IN SAO-PAULO AND RIO DE JANEIRO
}

\author{
MAXIME AUDOUIN \& CATARINA NEVES \\ Chair Management of Network Industries (MIR), College Management of Technology, EPFL, Switzerland
}

\begin{abstract}
Urban transportation is currently experiencing major changes, namely because of disruptive innovations driven by the information and communication technologies (ICTs). During the past few years, ride-booking has emerged in many cities around the world as one of the most prominent new disruptive mobility services, impacting urban transportation systems and creating unprecedented regulatory challenges for local authorities. This paper will compare the development and implementation of different regulatory approaches used in two South American cities. We first review the existing literature to assess the research gap in the regulation of ICT-based innovative mobility services. Then, through two exploratory case studies, mainly based on archival data such as newspaper articles and government publications, we present the regulations developed during the last 2 years in Rio de Janeiro and São Paulo in Brazil concerning the globally known ride-booking service UBER. These two cities, while geographically and demographically similar, have taken opposite stances on ride-booking regulation, with São Paulo pushing for integration and Rio de Janeiro pushing for banishment. By comparing these two cases, and looking at how foreign cities deal with the issue of ride-booking regulations, this paper proposes three different regulatory approaches, and ultimately contributes to the growing literature focusing on ICT-facilitated disruptive services regulations. We conclude the paper by highlighting future research needs in the area of digital urban transportation.

Keywords: TNCs, regulation, UBER, disruption, ICTs, ride-booking.
\end{abstract}

\section{INTRODUCTION}

For the past decade, the Information and Communication Technologies (ICTs) have penetrated urban infrastructure systems and been responsible for having supported the birth of new "digital" urban services [1]. Among other sectors, such as accommodation or energy, the transportation sector appears to be the one having been the most disrupted by these new ICT-based services. The ICTs have for example facilitated the development of car sharing schemes, where specific organizations provide their customers with an access to a fleet of shared vehicles on a short-term basis, ultimately leading to the reduction of private vehicle ownership need [2]. Through the creation of dedicated platforms, the ICTs have also enabled ridesharing schemes to come to life, where vehicle owners allow other passengers to join their ride to and from the similar destination, in order to share costs [3]. At the forefront of these disruptive ICT-supported transportation services probably sit ride-booking services, also called ride-sourcing or Transportation Network Companies (TNCs), where individuals are able to propose their own vehicles, still on specially created platforms, to address other individuals' mobility needs in exchange for a fee.

Globally, the ride-booking sector has been dominated by UBER, founded in 2010, operating, as of March 2017, in over 480 cities in 70 countries, connecting 1.5 million drivers to about 50 million active users worldwide. However, due to its disruptive nature, UBER and more generally ride-booking services have created a series of adaptation challenges that have triggered the interests of academics, as we have tried to summarize as follows. 
Scholars have been interested to understand the environmental and economic impacts of ride-booking services. Carranza et al. [4] per instance found that individuals using UBER for all their mobility needs would emit significantly less travel-related $\mathrm{C} 02$ emissions than individuals splitting travels in half between UBER and driving their own car. However, it is also showed that the more environmental friendly scenario would translate in higher economic costs for users. Research has also been carried out to understand the social acceptance of ride-booking services. It has been for example showed by Garikapati et al. [5], that millennials are more likely to accept UBER than other age groups. Ride-booking services have triggered the interest of Management scholars, who have been interested in studying UBER underlying business models. Schor [6] for example denounces the bad practices of for-profit ride-booking companies, while she underlines the real potential of ride-booking if it is peer-to-peer.

In general, most scholars have been interested to understand the impact of UBER on other transportation modes. Hoffmann et al. [7] have for example demonstrated that ridebooking and subway usage were positively correlated in NYC. Interested in knowing the impact of ride-booking services on the taxi industry, Rayle et al. [8] for example showed that in the case of San Francisco, ride-booking services were serving an unprecedented travel urban travel demand. Highlighting the impact of ride-booking services on the traditional taxi industry, scholars have emphasized the need for public authorities to develop innovative regulations. For example, Strong [9] highlighted that the environmental impacts of ride-booking services will be highly dependent on how they are regulated, for instance, by ensuring only recent car models are used, or going even further, by requiring high levels of efficiency or even the use of specific fuels in vehicles. Feeney [10] highlighted the need to regulate ride-booking services for security purposes. Edelman and Geradin [11] also highlighted the need for public authorities to regulate UBER, by either resisting UBER or developing a level playing field for both taxis and UBER.

While research about UBER regulation has been conducted for Europe and the United States [12], there seems to be a research gap about how UBER is being regulated in South and Latin America. With urbanization rates averaging $80 \%$ and UBER offering its services in over 65 cities in the region, totalizing for example 45 million trips in Latin America for the only month of August 2016 [13], the ride-booking Latin American markets must not be ignored. Apart from a study of ride-booking regulation in Mexico and Colombia [14], there seems to be very little research about ride-booking regulation in South and Latin America.

With $85 \%$ of the population living in urban areas [15], and with about $80 \%$ of the total population using a smartphone [16], Brazil appeared to be the perfect environment for UBER to start their operations, which finally happened back in 2014. Today, Brazil is considered to be UBER's third biggest market globally, where São Paulo is considered number two UBER's busiest city worldwide [17]. The arrival of UBER in the country has been followed by several protests organized by the disrupted taxi sector, which pushed the authorities to adopt new regulatory frameworks. In this paper, we explore, using mainly archival data such as newspaper articles and government publications, the processes of regulatory adaptation to ride-booking solutions in São Paulo and Rio de Janeiro, which adopted opposite regulatory positions to the entry of UBER. By comparing these two cases, this paper proposes three different regulatory approaches to the entry of ride-booking services, and ultimately contributes to the growing literature focusing on ICT-facilitated disruptive services regulations. 


\section{CASE STUDIES}

With respectively about 21 and 13 million inhabitants [18], São Paulo and Rio de Janeiro are Brazil's largest cities, both facing consequent mobility demands. Almost a year after breaking the Latin American market in Mexico City, UBER was introduced in Brazil in Spring 2014. Proposing an alternative to traditional urban transportation modes, UBER quickly became popular in both cities. Linking 50,000 drivers to more than 8 million customers, UBER was available in over 30 cities across Brazil as of September 2016. This impressive expansion however has not happened unhindered, mainly because of the important resistance encountered from taxi drivers and respective unions. In Brazil, according to the federal law, taxi drivers must hold a dedicated taxi-driving license to exercise their functions, which are supposed to be free of charge. However due to the fact that Rio and São Paulo governments stopped emitting licenses back in 1996, despite growing taxi demand resulting from urban growth, an important illegal market for the sale and rent of taxi licenses has emerged. When not renting them illegally for a periodic fee, individuals nowadays usually have to disburse between USD 15,000 to USD 40,000 to acquire taxi-driving licenses [19], which is the main reason they have been accusing UBER of unfair competition, since UBER drivers were not required to hold any particular permit when they started their operations. Each city explored in this paper adopted its own strategy on how to regulate UBER. While using similar approaches at first, the two governments quickly diverged on their regulations. The following section provides a step-by-step history of the regulatory process in Rio de Janeiro and São Paulo.

\subsection{Rio de Janeiro}

On the 15th of May 2014, and in preparation for the 2014 Football World Cup to be hosted in Brazil the same year, UBER was introduced in Rio de Janeiro. Following numerous protests from most of the 32,000 taxi driving license holders, accusing UBER of unfair competition, the City of Rio filed in December 2014 a police complaint against ride booking companies, underlining the illegal nature of such activities [20]. The Rio de Janeiro city council finally voted on August 25th, 2015 the banishment of unregulated ride-booking services, such as UBER. The bill also planned to have all ride-booking drivers continuing operations fined R\$2 2000 (USD 550) [21], which finally came into law, following its signature by Rio de Janeiro Mayor Eduardo Paes, from the Brazilian Democratic Movement Party. The Rio State Court of Public Finance issued an injunction on September 8th of 2015 deciding to suspend UBER's banishment, stating that there was inexistent legitimate justification for the State to prevent ride-booking activities. The Court injunction thus allowed UBER drivers to continue their activity, but also intended at protecting them, since any entity attempting to have an impact on their activities would be fined R \$ 50,000 (USD 16,000) [22]. Going against the State Court decision, Mayor Paes ratified on September 30th, 2015, a decree targeting ride-booking drivers and companies, specifying that any individual caught transporting passengers without holding a dedicated license would be automatically fined R\$ 1360 (USD 440), have their vehicles potentially confiscated, and issue a fine of R\$ 2000 (USD 650) to the ride-booking company they operate for [23]. The decree did not apply to car-poolers as far as they were not proposing more than two journeys a day. In response to the decree, UBER motivated its users to send emails to Rio de Janeiro's City Hall to show their discontent and their attachment to their mobility solution. This resulted in 700,000 emails sent by users and citizens to the City Hall asking them to veto the decree [24]. In April of 2016, the Rio State Court of Public Finance issued an injunction that allowed UBER to legally circulate in the city of Rio de Janeiro [25]. As the transport department of the City of 
Rio, as well as the Road and transport department of the State of Rio must abide the State of Rio Courts decisions, they were not allowed to impose fines, seize vehicles or perform any acts that would have restricted or make UBER's services impossible, at the risk of the city paying a fine of R \$50,000 (USD 16,000) each infraction. According to State of Rio Court, traditional taxi rides and rides provided through ride-booking platforms by individuals, must be understood as different mobility solutions, and thus must not comply to the same regulations [25].

Anticipating the upcoming Court decision, taxi drivers organized an important protest on April 1st, 2016, calling the authorities to ban UBER again, arguing that ride-booking services were responsible for a decrease of activity in the taxi sector of up to 60\% [26]. Answering taxi drivers' protests, Mayor Paes signed on 28th of November 2016 a new municipal law, voted by the City Council, prohibiting the use of private vehicles for the paid transport of passengers in the city. However, this law did have any impact as the Rio State Court decided not to withdraw its April decision protecting ride-booking drivers and companies. Since then, the City of Rio has appealed the State Court of Public Finances injunction at the Civil Court branch of Rio's State Court, but the process is still ongoing. As of today, UBER is not regulated but is still allowed to operate due to the State Court injunction.

\subsection{São Paulo}

On June 2014, UBER was introduced in São Paulo. Following almost a year of discontent and protests, the Syndicate for Drivers and Workers of Taxi Companies in the State of São Paulo demanded in June 2015 the immediate banishment of the UBER services by the Justice Court of the São Paulo State. Based on the arguments that UBER was providing taxi services without following proper taxi regulations, the Syndicate required the app to be blocked from public access, which was finally approved by the Court. The Court decision also obliged UBER to pay the state of São Paulo a penalty of R 100,000 (approximately USD 32,000) a day, that could increase up to R $\$ 5$ million (or about USD 1.6 million), as far as they would continue their operation. The court decision also required that Google, Apple, Microsoft and Samsung ceased providing the app in their app store and remotely suspend the app of users having already installed it. In June of 2015, São Paulo city council approved the law PL $349 / 2014$, prohibiting the commercial use of private cars, through apps, to transport people establishing a fine of $\mathrm{R} \$ 1700,00$ (USD 550) for ride-booking drivers as well as vehicle apprehension. The law also enabled the city government to conduct studies to understand how the ICTs could be used to improve transportation system.

In trying to find a middle ground for the regulation of UBER, the mayor of São Paulo, Mr. Fernando Haddad, elected in 2012 for the leftist Worker's Party, announced in October 2015 the creation, through official decree $\mathrm{n}^{\circ} 56489$, of a new taxi category: the black cabs, which could only be booked through apps (ride-booking), and not on the streets. Mayor planned to distribute special Licenses to operate black cabs through a lottery for an individual cost of R $\$ 60000,00$ (USD 20,000), payable in 60 monthly instalments, to prevent illegal reselling. Black cabs were able to charge up to $25 \%$ more than the regular taxi service in the city and could only receive payments through the apps, avoiding the need to have them equipped with taximeters. It was also stipulated in the decree that $25 \%$ of all black cab licenses would be issued to women, as an attempt to fix the gender disparities in the sector. For 5000 licenses available, over 27,000 people registered for the lottery of black cab licenses, which closed on November 30th, 2015 [27].

However, UBER continued claiming it should not be considered a taxi service [28] and rejected the decree, continuing operating as before. This pushed São Paulo City council to 
amend law PL 349/2014 in January 2016 and increase the fine to ride-booking drivers to R\$ 4500,00 (USD 1,400). Although some cars were actually seized, and fines were paid by UBER [29], the law PL 349/2014 was finally overturned by the Sao Paulo State Court after the National Services Confederation requested a review on the constitutionality of the decision [30].

Trying to accommodate the rising demand for UBER and the continued lack of regulation, Mayor Haddad established in October 2015 the creation of an expert group on new individual transport services regulation. Upon the completion of the expert group studies, two parallel solutions were proposed. For services providing paid individual transportation, such as UBER, drivers would have to acquire special credits to operate, while for individuals providing carpooling services, no special arrangements were required. Under this scenario, UBER drivers would be asked to purchase kilometer credits upfront, sold once a week and valid for two months after purchase. The way credits were deducted was meant to incentivize use of ride-booking services to cope with the city's transportation system weaknesses. For instance, drivers providing their rides off peak, in the city outskirts, using disability adapted vehicles or having high car occupancy (minimum of four people), would be charged less credits for their operations than if operating at peak hours and having small number of passengers. To be able to buy "UBER" credits, UBER drivers were also asked to register as such to the city government [31]. In order to allow UBER drivers to get UBER credits, UBER was to provide live data of all UBER trips, including origins, destinations, routes, distances and times to the city authorities, so they could get a better understanding of Sao Paulo citizens mobility needs [32]. This proposition to regulate UBER was open for public consultation for 30 days at the beginning of 2016, and was very well received by both the population and the ride-booking company. Mayor Haddad planned to implement this regulation by decree in order to avoid any political blockage in the vote of the law by the city council. Because of the introduction of the very advantageous car-pooling regulation by the city, UBER, even though still proposing traditional UBER services, introduced in May 2016 UBERPOOL. The service proposed matching riders with other riders going in the same direction, thus allowing them to share the costs of an UBER ride without significant losses in time. Finally, on May $10^{\text {th }}, 2016$, the mayor signed the decree no. 56981 into law, which was embraced by UBER and other similar ride booking companies. The kilometer credits price was set at an average of $\mathrm{R} \$ 0,10 / \mathrm{km}$ and the credit scheme was modified, with the government opting to charge for the credits after each ride instead of a pre-paid scheme. The implementation of a downstream rather than upfront credit mechanism was made possible as UBER and ride booking companies agreed to share all their trip data with public authorities, so they could monitor UBER drivers' activities. The proposed credit mechanism aimed at absorbing the demand for rides in the city, as the number of inhabitants per cab available was much lower than other metropolises [33].

In September of 2016, Sao Paulo State Court issued a mandate for the city government to limit the number of available UBER cars in São Paulo, at the risk of a daily fine of R $\$ 500,000$ (or approximately USD 160,000) to be paid by the city. At the time, former Mayor Fernando Haddad clarified that such measure was already included in the decree no. 56981 of May 2016, by establishing a limit of 5,000 "car equivalents" a month. A "car-equivalent" was measured based on the average distance driven by a regular taxi over a month, and at the time the number of "car-equivalents" in circulation was well below 5,000 a month [34]. This measure was complemented in October 2016 by a new regulation along which each ridebooking company's fleet was not allowed to drive more $7500 \mathrm{~km}$ per hour in total. If ridebooking companies exceeded this value, for which authorities would be aware as they have access to UBER data, the tax charged per kilometer would increase from $\mathrm{R} \$ 0.10$ to up to $\mathrm{R} \$$ 
0.30 [35]. UBER quickly appealed this new regulation to the Sao Paulo State courts, which overturned the mayor's tax surcharge [36].

By incentivizing through credit deductions UBER drivers to run at times or places in which public transport is limited, Mayor Haddad demonstrated his interest in using UBER as a complement to his city public transport system weaknesses. In order to fully integrate UBER with the rest of São Paulo's transport system, Mayor Haddad also proposed to allow customers to use their transport Smart Card, named Bilhete Único, to pay for UBER [37], but this innovative idea was never implemented.

In 2016 municipal elections were held, and won by Mr. João Dória, from the right leaning Brazilian Social Democracy Party. Although the latest regulations from the Haddad administration are still in place, wherein today, UBER and other ride-booking services continue to operate under a R\$ 0.10-kilometre credit, with no hard limits on the number of actual vehicles in circulation, it is uncertain they will remain in place, as São Paulo's new mayor has already expressed his interest in finding ways to further regulate ride-booking services [38]. In February 2017 Mayor Dória also revealed that the number of actual cars providing rides had surpassed the number of taxi drivers in the city $(50,000 \mathrm{vs} .38,000)$. With an estimate that 9 out of 10 of these ride-booking cars were operating as UBER, one must expect new regulations to come soon.

\section{ANALYSIS}

In the following part, we analyze and compare the regulations developed in Rio and São Paulo. We also compare them to other regulatory approaches that have been used in North America and Europe to finally propose three categories of regulatory intervention to ICTfacilitated ride-booking services.

Regulatory interventions on private passenger transport are usually divided into the following four categories [39]; quality regulation, quantity regulation, price regulation and market conduct regulation. Quality regulation is concerned with ensuring safety and minimum quality standards for passengers, through standards for vehicles (age, type,

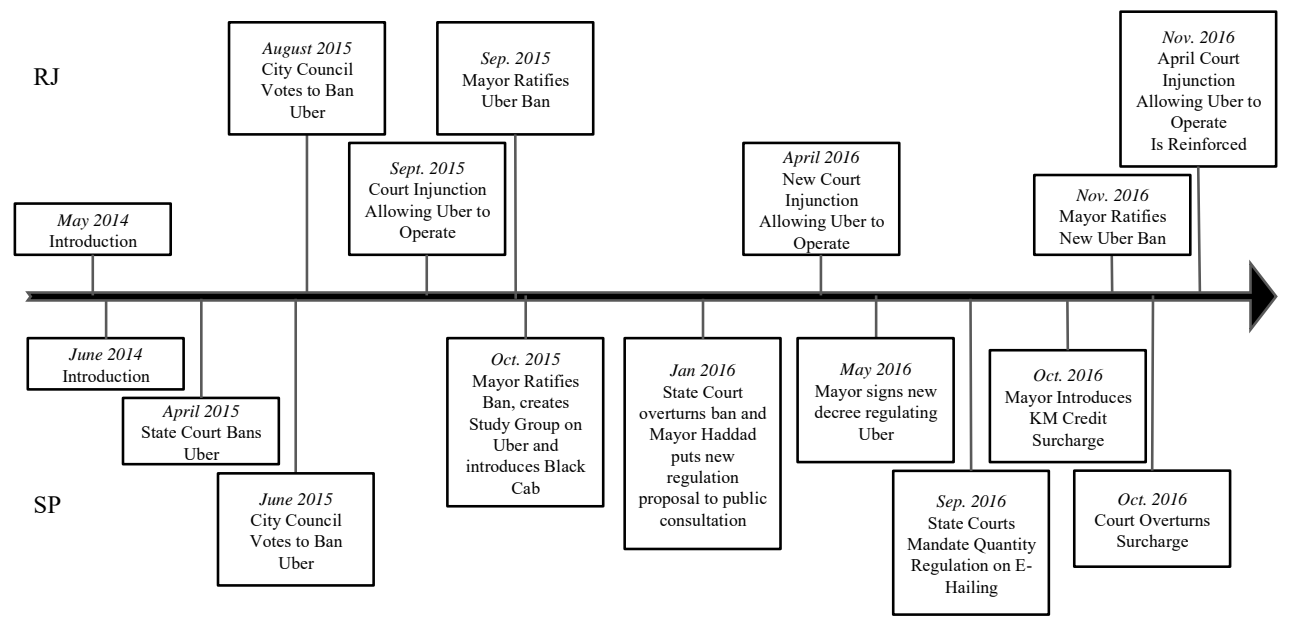

Figure 1: Evolution of ride-booking services regulation in Rio de Janeiro and São Paulo. 
Table 1: Comparison of regulatory approaches in São Paulo and Rio de Janeiro.

\begin{tabular}{|l|l|l|l|l|l|}
\hline & & $\begin{array}{l}\text { Quality } \\
\text { regulation }\end{array}$ & Quantity regulation & $\begin{array}{l}\text { Price } \\
\text { regulation }\end{array}$ & Market conduct regulation \\
\hline RJ & Addressed? & - & - & - & - \\
\hline & Impact & $\begin{array}{l}\text { - No customer } \\
\text { security } \\
- \text { Poor customer } \\
\text { experience }\end{array}$ & $\begin{array}{l}\text { - No control on the } \\
\text { environmental or } \\
\text { congestion impacts }\end{array}$ & $\begin{array}{l}\text { - Threat to } \\
\text { customer } \\
\text { access } \\
- \text { Monopoly }\end{array}$ & $\begin{array}{l}- \text { Threat to existing } \\
\text { transportation modes, } \\
\text { including Public Transport }\end{array}$ \\
\hline SP & Addressed? & + & $+/-$ & - & + \\
\hline & Impact & $\begin{array}{l}- \text { Customer } \\
\text { security } \\
- \text { Customer } \\
\text { experience }\end{array}$ & $\begin{array}{l}\text { - Control of the } \\
\text { environmental and } \\
\text { congestion impact }\end{array}$ & $\begin{array}{l}- \text { Threat to } \\
\text { customer } \\
\text { access } \\
- \text { Monopoly }\end{array}$ & $\begin{array}{l}\text { - Complementarity of } \\
\text { Ride booking services } \\
\text { with existing } \\
\text { transportation services }\end{array}$ \\
\hline
\end{tabular}

maintenance) and standards for the driver ("fit and proper person" tests, formal qualifications requirements, insurance, etc.). Quantity regulation consists of restricting the number of taxis able to be licensed. Price regulation is usually used as consequence of quantity restrictions by regulating prices in order to limit the ability of incumbents to extract monopoly rents. Finally, other forms of regulation can be classified as market conduct regulation: examples include requirements for taxis to pick up all passengers and rules regarding issues such as shared hire arrangements.

São Paulo's regulatory approach to ride-booking services focused on three of the four above-mentioned categories. Quality regulation was introduced through clearly defined requirements regarding vehicle age and working conditions. Quantity regulation was much more loosely introduced, through the use of a proxy of quantity, namely "car equivalents". By regulating the total amount of kilometer driven, and not the amount of UBER drivers, Sao Paulo adopted a rather liberal approach, in order to benefit most of the ride-booking drivers. Indeed, as most of them are operating part time, Sao Paulo took the decision not to apply to them traditional quantity regulation, that are usually applied to the taxi industry. Price regulations were not yet addressed. Since UBER's fares are calculated on the trip length and duration, and directly sent to the customers by email right after the ride, the legislation did not particularly focus on issues of fare transparency or structure. Finally, market conduct regulations were introduced through the development of UBER credits, which aimed at incentivizing drivers to provide rides to certain locations and for certain customers.

Conversely, by simply banning UBER (albeit unsuccessfully), Rio de Janeiro failed to introduce any meaningful regulations. As it stands, there are no quality or market conduct rules that UBER must comply with, thus exposing customers to security issues, and failing to guarantee them a certain level of service. The absence of quantity regulation might also be perceived as a threat to the transportation system performance. If the number of UBER driver keeps growing, should there be sufficient demand, traffic congestion could indeed be worsened. Ultimately the absence of pricing regulation might also be harmful for customers (surge pricing) as well as for the taxi industry (unfair competition). While the former mayor of São Paulo had an overall progressive and inclusive approach to urban mobility throughout his eight-year term, the same was not true for Rio de Janeiro, which resulted in a wide divergence in their regulatory approach. We believe that Rio de Janeiro should take up some of the lessons from São Paulo, and adapt them to their own circumstances.

We can however criticize the lack of consideration of the following points in the regulation developed in Sao Paulo. 
Price regulation for example could have been introduced regarding surge pricing. In order to incentivize drivers to operate certain hours, UBER usually applies surge pricing, so drivers get more money for the rides they provide. Surge pricing can in certain cases be quite high and painful for the customers, which is why Sao Paulo authorities could have paid attention to it, killing two birds with one stone. Quality regulation could have been better explored as well. In some cities, such as London [40], quality regulations have been developed, including the necessity for UBER drivers to pass a language test to be able to operate, to be sure drivers are able to communicate with their customers. There are also labor regulation issues. For example, UBER drivers have actually the legal status of self-employed workers, and because of that are not guaranteed the same labor workers right as normal employees. That has led in France of protests from UBER drivers, who, in late 2016, entered a strike to denounce the very poor employment conditions of their company, following an increase of the overhead taken by UBER on each ride from 20 to $25 \%$ [41]. Despite the regulatory limbo in which UBER has operated the past years (and still operates in some cities, such as Rio) UBER remains largely successful and seems close to achieving a monopoly among ride-booking services in the country. This will bring forth new discussions on market regulation, especially antitrust laws at the state or even the federal level, which will probably lead to a new legal battle.

Albeit it opposed many regulatory trials in both São Paulo and Rio de Janeiro, UBER has finally embraced São Paulo's latest “credits" regulation. By refusing to adhere to previous regulatory attempts, such as banishment, UBER, thanks to high public support, growing demand, and sufficient funds, was able to hold the line and push for what turned out to be a fairer and more constructive solution for most parties. By continuing to condemn the banishment from the city of Rio, UBER seems to be adopting the same approach to see things change in its interest.

If there is one element that has however remained unchanged since the introduction of UBER, regardless of the regulations introduced in Rio and Sao Paulo, it is probably the grievances of the taxi drivers, who still see ride-booking activities as negatively impacting their businesses. Although it was demonstrated that UBER was responding to a "suppressed demand" of customers who were not accustomed to taxi services prior to its introduction [42], most taxi drivers still consider UBER and ride-booking services as unfair competition. However, finding a fair solution to tackle this issue is a real challenge since that most of the taxi drivers in both cities are operating with licenses obtained illegally. While re-designing regulation for newcomers appears a simpler exercise, as done for "black cabs" in Sao Paulo, making amends in an efficient and legal way to those who already invested thousands of dollars in an illegally traded license requires even more innovative policy making: when deregulating the taxi sector, should public authorities develop any specific measures to compensate the actors that are being disrupted? Looking abroad, Fort Worth in Texas for example, has decided to create a level-playing field by fully deregulating the taxi industry. During summer 2016, a new vehicle-for-hire regulation came into law, requiring all motorized and non-motorized companies to pay a USD 500 operating license good for two years, as well as forcing all motorized vehicle hailed from the streets to be equipped with a meter [43]. While this solution was largely embraced by ride-booking companies, including UBER, one might wonder the rightness of this solution for the taxi industry, where each taxi driver used to disburse an important amount of money to buy their medallions. Massachusetts has opted for less radical option by voting a state-wide regulation in summer 2016 which imposed on all ride sharing drivers a 20 cents charge per ride, with half going to the municipality where passengers are picked up, and the rest equally split between the state Department of Transportation and the MassDevelopment fund, which is then partially used 
to subsidy traditional taxi operators [44]. Even though this regulation might seem innovative at first sight, it will unfortunately directly impact the customers, as the 20 cents will rather be coming out of their pockets than from the drivers or ride-booking companies. When regulating ride-booking companies, authorities must pay attention to protecting customers and citizens.

Most of ride-booking regulations currently in place worldwide, including those developed in São Paulo and Rio de Janeiro, cannot be expected to be definitive. Rio's solution is unstable simply because UBER will continue to operate in the city, forcing State or even federal legislators to eventually find a different solution that accounts for the public's support and adoption of the app. Still looking abroad, this for example what happened in Finland, where despite the ban, UBER keeps operating in Helsinki [45]. São Paulo's regulation might also not stay in place given the political agenda of the newly elected mayor. In order to find a sustainable solution for both traditional taxi and ride booking companies, Geradin proposes to develop a unique regulation for both sectors, which should contribute to making both industries converge to a middle ground between current ride-booking and taxi industries [46]. Taxis, as they already started to do in São Paulo, for example need to modernize themselves, by enabling digital payments, and using geo-localization technologies to better match the demand. Ride-booking services, on the other hand, need to be more regulated in terms of quality and price.

\section{CONCLUSION}

Through a comparative analysis between Rio de Janeiro and São Paulo, this paper aimed at understanding in practice how cities are adapting their regulatory framework introduction of disruptive ICT-based mobility services, and more specifically to ride-booking services. By comparing the two cases together, and also paying attention to how the problem or ridebooking regulation was considered outside Brazil, it appears that ride-booking regulation can fall within three major categories. The first one is the laissez-faire approach, which both Rio de Janeiro and São Paulo adopted at the very first, and which many cities still adopt. The second is outright banning, which has been adopted by Rio de Janeiro but also by other major cities (to different services), such as Finland or Spain. Lastly, there are those attempting to create innovative and forward-looking regulations on the ride-booking service sector. These include full de-regulation of the taxi sector or regulations trying to establish middle grounds between taxi and ride-booking companies. However, within this category, many problems seem to be still left unsolved, such as the competition with the taxi sector, the deregulation of the taxi sector and the question of ride-booking monopolies. Thus, we believe more research should be carried out to see how ride-booking services are being regulated, and more specifically to understand the efficiency of some of these regulations. UBER has also been facing criticisms for charging its drivers more and more, and for increasingly using public roads without financially contributing to their maintenance, thus calling for the development of new business models, which will also call for new regulatory arrangements. We believe management scholars should conduct deeper research in that direction. As UBER and other ride-booking services are spreading worldwide and encountering net success from the public, one must now wonder how to integrate these services to traditional public transportation services so they are complementary and they help fighting congestion and urban transportation systems inefficiencies. If research must be conducted to explore the technicalities of such integrated schemes, we also must underline the need to conduct research to understand the role that public authorities will play in the development of such integrated and digital urban mobility systems. 


\section{REFERENCES}

[1] Finger, M. \& Razaghi, M., Conceptualizing "Smart Cities". Informatik-Spektrum, pp. $1-8,2016$.

[2] Shaheen, S., Cohen, A. \& Chung, M., North American car sharing: 10-year retrospective. Transportation Research Record: Journal of the Transportation Research Board, 2110, pp. 35-44, 2009.

[3] Cohen, B. \& Kietzmann, J., Ride on! Mobility business models for the sharing economy. Organization \& Environment, 27(3), pp. 279-296, 2014.

[4] Carranza, V., Chow, K., Pham, H., Roswell, E. \& Sun, P., Life Cycle Analysis: UBER vs. Car Ownership. Environment, 159, pp. 1-19, 2016.

[5] Garikapati, V., Pendyala, R., Morris, E., Mokhtarian, P. \& McDonald, N., Activity patterns, time use, and travel of millennials: a generation in transition? Transport Reviews, 36(5), pp. 558-584, 2016.

[6] Schor, J., Debating the sharing economy. Journal of Self-Governance and Management Economics, 4(3), pp. 7-22, 2016

[7] Hoffmann, K., Ipeirotis, P. \& Sundararajan, A., Ridesharing and the Use of Public Transportation, AIS Electronic Library, 2016.

[8] Rayle, L., Dai, D., Chan, N., Cervero, R. \& Shaheen, S., Just a better taxi? A surveybased comparison of taxis, transit, and ride sourcing services in San Francisco. Transport Policy, 45, pp. 168-178, 2016.

[9] Strong, K.C., When Apps Pollute: Regulating Transportation Network Companies to Maximize Environmental Benefits. U. Colo. L. Rev., 86, pp. 1049-1093, 2015.

[10] Feeney, M., Is Ridesharing Safe? Cato Policy Analysis, 767, pp. 1-15, 2015.

[11] Edelman, B.G. \& Geradin, D., Efficiencies and regulatory shortcuts: How should we regulate companies like Airbnb and UBER. Stanford Technology Law Review, 19, pp. 293-328, 2015.

[12] Rauch, D. \& Schleicher, D., Like Uber but for local governmental policy: the future of local regulation of the "Sharing Economy", George Mason University Law and Economics Research Paper Series, 15(01), 2015.

[13] Newcomer, E., Can Uber conquer Latin America? Bloomberg (Oct. 2016), Online. https://www.bloomberg.com/news/articles/2016-10-13/can-uber-conquer-latinamerica. Accessed on: 24 Mar. 2017.

[14] Puche, M.L., Regulating e-hailing services: the case of UBER Regulation in Mexico City and Bogota', Master Thesis, IGLUS, EPFL, 2016.

[15] United Nations, Department of Economic and Social Affairs, Population Division. World Urbanization Prospects: The 2014 Revision, Highlights (ST/ESA/SER.A/352), 2014.

[16] Meirelles, F.S., Tecnologia de Informa ção, Presentation made at the 27a Pesquisa Annual do Uso de TI, 2016, Online. http://eaesp.fgvsp.br/sites/eaesp.fgvsp.br/files/ pesti2016gvciappt.pdf. Accessed on: 24 Mar. 2017.

[17] Felitti, G., Uber: um histórico de violência dos taxistas contra os carros pretos no Brasil, Epoca Negocios (Oct. 2015), Online. http://colunas.revistaepocanegocios. globo.com/tecneira/2015/10/06/UBER-um-historico-de-violencia-dos-taxistas-contra -os-carros-pretos-no-brasil/. Accessed on: 24 Mar. 2017.

[18] United Nations. The World's Cities in 2016: Data Booklet, 2016, Online. http://www.un.org/en/development/desa/population/publications/pdf/urbanization/the _worlds_cities_in_2016_data_booklet.pdf. Accessed on: 24 Mar. 2017. 
[19] Magalhães, L., Plano Diretor estabelece o limite de um taxi para cada 700 habitantes, Globo (Dec. 2010), Online. http://oglobo.globo.com/rio/plano-diretor-estabelecelimite-de-um-taxi-para-cada-700-habitantes-2915986. Accessed on: 3 Apr. 2017.

[20] Orihuela, R., UBER weighs Spain appeal as bans go from Rio de Janeiro to Delhi, Livemint (Dec. 2014), Online. http://www.livemint.com/Companies/r8eDouH354Yla rEkDiLxaP/UBER-weighs-Spain-appeal-as-bans-go-from-Rio-de-Janeiro-to-D.html. Accessed on: 31 Mar. 2017.

[21] Elizardo, M., Câmara do Rio aprova lei que prevê multa a motorist do Uber, G1 (Aug. 2015), Online. http://recode.net/2015/08/25/rio-de-janeiro-city-council-votes-to-banuber/. Accessed on: 3 Apr. 2017.

[22] Barreira, G., Liminar permite Uber no Rio e suspende lei publicada por Paes, Globo (Sep. 2015), Online. http://g1.globo.com/rio-de-janeiro/noticia/2015/10/uber-diz-terdecisao-judicial-que-anula-proibicao-de-circulacao-no-rio.html. Accessed on: 27 Mar. 2017.

[23] Kokalitcheva, K., Rio De Janeiro Mayor Signs Bill to Ban UBER and Others, Fortune (Sep. 2015), Online. http://fortune.com/2015/09/29/rio-de-janeiro-bans-UBERbrazil/. Accessed on: 27 Mar. 2017.

[24] Viga Gaier, R., Rio de Janeiro mayor bans UBER, open to debating regulation, Reuters (Sep. 2015), Online. http://www.reuters.com/article/us-UBER-tech-brazilidUSKCN0RT2X020150929. Accessed on: 27 Mar. 2017.

[25] Thomé, C., Decisão da Justiça torna Uber legal no Rio, O Estado de S. Paulo (Apr. 2016), Online. http://brasil.estadao.com.br/noticias/rio-de-janeiro,decisao-da-justicatorna-uber-legal-no-rio,10000025041?success=true. Accessed on: 3 Apr. 2017.

[26] Freitas, B., Rumores, WhatsApp e mudanças à vista: o duelo Olímpico Uber x taxistas, UOL (Aug. 2016), Online. https://olimpiadas.uol.com.br/noticias/redacao/ 2016/08/09/uber-e-taxistas-encaram-batalha-olimpica-e-esperam-mudancas-apos-ario-2016.htm. Accessed on: 3 Apr. 2017.

[27] Domingues, R., Prefeitura de SP cria 5 mil novos alvarás e lança categoria 'táxi preto', Globo (Aug. 2016), Online. http://g1.globo.com/sao-paulo/noticia/2015/10/prefeiturade-sp-cria-5-mil-novos-alvaras-e-lanca-categoria-de-taxi-preto.html. Accessed on: 3 Apr. 2017.

[28] Fabio, Nota sobre a sançao do PL 349/14 em São Paulo, UBER Newsroom (Oct. 2015), Online. https://newsroom.uber.com/brazil/nota-sobre-a-sancao-do-pl-34914-em-saopaulo/. Accessed on: 3 Apr. 2017.

[29] Rodrigues, A. \& Russo, R., Uber banca multa e mantém motorista clandestino tranquilo em São Paulo, Floha de Sao Paulo (Oct. 2015), Online. http://www1.folha.uol.com.br/cotidiano/2015/10/1692631-uber-banca-multa-emantem-motorista-clandestino-tranquilo-em-sao-paulo.shtml. Accessed on: $31 \mathrm{March}$ 2017.

[30] Prefeitura de São Paulo. Prefeitura insiste na regulamentação do Uber (Apr. 2016), Online. http://capital.sp.gov.br/noticia/prefeitura-insiste-na-regulamentacao-do-uber. Accessed on: 3 Apr. 2017.

[31] Leite, I., Entenda as propostas para regular o Uber e outros aplicativos em SP, Globo, (Dec. 2015), Online. http://g1.globo.com/sao-paulo/noticia/2015/12/entendapropostas-para-regular-o-uber-e-outros-aplicativos-em-sp.html. Accessed on: 3 Apr. 2017.

[32] Jaffe, E., São Paulo Offers the Best Plan Yet for Dealing With Uber, CityLab (Jan. 2016), Online. http://www.citylab.com/cityfixer/2016/01/sao-paulo-uber-trafficcongestion-mileage-fee/433764/. Accessed on: 3 Apr. 2017. 
[33] Prefeitura de São Paulo. Decreto municipal regulamenta transporte individual de passageiros, (May 2016), Online. http://www.prefeitura.sp.gov.br/cidade/secretarias/ transportes/noticias/?p=216945. Accessed on: 3 Apr. 2017.

[34] De Oliveira, Justiça manda Haddad limitar veículos do Uber, Diario de S. Paulo, Diario SP (Sep. 2016), Online. http://www.diariosp.com.br/noticia/detalhe/94065/justicamanda-haddad-limitar-veiculos-do-UBER. Accessed on: 27 Mar. 2017.

[35] Ribeiro, B., Haddad cria sobretaxa para combater monopólio da Uber no transporte de SP, O Estado de S. Paulo, (Oct. 2016), Online. http://saopaulo.estadao.com.br/noticias/geral,haddad-cria-sobretaxa-para-combatermonopolio-da-uber-no-transporte-de-sp,10000081334. Accessed on: 3 Apr. 2017.

[36] Bergamim, G., Contra monopólio, Haddad aumenta taxa para aplicativos como Uber, Folha de S. Paulo (Oct. 2016), Online. http://www1.folha.uol.com.br/cotidiano/2016/10/1821589-contra-monopoliohaddad-aumenta-taxa-para-aplicativos-como-uber.shtml. Accessed on: 27 Mar. 2017.

[37] Bergamim, G., Haddad quer sistema para uso do Bilhete Único em táxi e Uber, Folha de S. Paulo (May 2016), Online. http://www1.folha.uol.com.br/cotidiano/ 2016/05/1768828-haddad-quer-sistema-para-uso-do-bilhete-unico-em-taxi-e-uber. shtml. Accessed on: 27 Mar. 2017.

[38] Pinho, M., Doria afirma ser a favor de funcionamento do Uber em São Paulo, Globo, (Sep. 2016), Online. http:/g1.globo.com/sao-paulo/eleicoes/2016/noticia/ 2016/09/doria-afirma-ser-favor-de-funcionamento-do-uber-em-sao-paulo.html. Accessed on: 3 Apr. 2017.

[39] OECD. Taxi Services: Competition and Regulation, 2007. http://www.oecd.org/regreform/sectors/41472612.pdf. Accessed on: 25 Mar. 2016.

[40] Toor, A., Uber loses challenge over English language tests for London drivers, The Verge (Mar. 2017), Online. http://www.theverge.com/2017/3/3/14800510/uberlondon-english-test-rules-court. Accessed on: 10 Mar. 2017.

[41] Bohineust, A., Uber: Les chauffeurs renoncent a la greve pendant la treve, Le Figaro (Dec. 2016), Online. http://www.lefigaro.fr/conjoncture/2016/12/27/2000220161227ARTFIG00008-uber-les-chauffeurs-renoncent-a-la-greve-pendant-la-treve. php. Accessed on: 10 Mar. 2017.

[42] Esteves, L.A., Rivalidade apos entrada: o impactor imediato do aplicativo Uber sobre as scorridas de taxi porta a porta, DEE, CADE, 2015, Online. http://www.cade.gov.br/acesso-a-informacao/publicacoes-institucionais/deepublicacoes-anexos/rivalidade-apos-entrada-o-impacto-imediato-do-aplicativo-ubersobre-as-corridas-de-taxi.pdf. Accessed on: 20 Mar. 2017.

[43] Baker, S., Uber, Lyft win deregulation efforts in Fort Worth, Star Telegram (June 2016), Online. http://www.star-telegram.com/news/local/community/fortworth/article86557452.html. Accessed on: 27 Mar. 2017.

[44] Lips, E., Boston-area cab companies take ride-app giant Uber to federal court, New Boston Post (December 2016), Online. http://newbostonpost.com/2016/12/16/bostonarea-cab-companies-taking-ride-app-giant-uber-to-federal-court/. Accessed on: 27 Mar. 2017.

[45] Satariano, A., Uber Drivers face Criminal Probes from Finland's Police, Bloomberg Technology, (August 2016), Online. https://www.bloomberg.com/news/articles/20168-16/uber-drivers-under-criminal-investigation-by-finland-s-police. Accessed on: 27 Mar. 2017.

[46] Geradin, D., Should UBER be allowed to compete in Europe? And if so how? George Mason University, Law \& Economics Research Paper Series, pp. 15-29. 